\title{
EDITORIAL
}

\section{Volume 26: Statistics and thanks}

During the 26th year of the International Journal of Technology Assessment in Health Care (IJTAHC), 154 original manuscripts were evaluated. Of these, 70 percent were from Europe and 14 percent from North America, as judged by the address of the first author. At the end of September 2010, sixty-four papers (42 percent of submissions) had been accepted for publication, seventy-two (47 percent) had been rejected, fourteen ( 9 percent) had been invited to submit a new version, and four ( 3 percent) were still in review.

The 266 authors of sixty-four published articles represented twenty-nine different countries and all continents. First authors were most often from the United Kingdom (28 percent), other countries in Europe (41 percent), or North America (17 percent). The balance between different types of articles reflects the varying interests of our authors and readers: in 2010, we published twenty-seven assessments of various health technologies, twenty-two methodological articles relevant for HTA, and fifteen papers describing the use of HTA in health policy processes.

The impact factor (IF) of the Journal has during the past 5 years been 1.3 or higher. In 2009, the IF reached its highest value ever: 1,794 . This reflects the 25 years of work by the founding editor Egon Jonsson. For journals with a limited number of articles, as most quarterly journals are, yearly variation in IF is the rule. In the era of increasing net publishing, impact factors seem to be on the increase.

On September 15, 2010, this Journal opened its Webbased Scholar One submission system. All submissions are now welcome at http://mc.manuscriptcentral.com/thc. All reviewers are also invited to register through this Web site. Papers first submitted before the opening date are reviewed and edited through traditional email correspondence. Double work during the transition lengthened waiting times; now we're back to the normal 8-12 weeks from submission to decision. The modernization is likely to result in faster reviewing schedules, and it will be possible to audit the process.

The quality of the journal depends very much on the support of its Editorial Board and other reviewers. This year the following persons have provided their wise comments on one or more manuscripts: Marja Airaksinen, John Sahl Andersen, Chuck Anderson, Heidi Anttila, Toni Ashton, Ione Auston, Ilona Autti-Rämö, Susanna Axelsson, Christel Bahtsevani, David Banta, Jeremiah Barondess, Mark Belletrutti, Marja Blom, Neill Booth, John Bridges, James Brophy, Reinhard Busse, Martin Buxton, Liza Chan, Irina Cleemput, Tammy Clifford, Tim Dall, Chris De Laet, Mike Drummond, Marina Erhola, Karen Facey, David Feeny, Atle Fretheim, Katrine Bjørnebek Frønsdal, Cecily Gilbert, Riitta Grahn, Scott Grosse, David Hailey, Nina Hakak, Flemming Juul Hansen, Elke Hausner, Seppo Heinonen, Akinori Hisashige, Bjørn Hofmann, Liisa Husu, Päivi Hämäläinen, Iñaki Gutierrez Ibarluzea, Tuija Ikonen, Jaana Isojärvi, Helena Isoniemi, Tiina Jahkola, Egon Jonsson, Jukkapekka Jousimaa, Kati Juva, Bengt Jönsson, Torben Jørgensen, Minna Kaila, Brendon Kearney, Martti Kekomäki, Eeva Ketola, Mette Just Kjølby, Scott Klarenbach, Gisela Kobelt, Vesa Koivukangas, Jorma Komulainen, Sérgio Kowalski, Ilkka Kunnamo, Regina Kunz, Frederic Lavoie, Sun-Hae Lee-Robin, Jaana Leipälä, Paul Lillrank, Diane Lorenzetti, Guy Maddern, Nea Malila, Antti Malmivaara, Shaila Mensinkai, Ruaraidh Milne, Espen Movik, Jukka Mäkelä, Mika Mäkelä, Suvi Mäklin, Berit Mørland, Duncan Neuhauser, Leo Niskanen, Wija Oortwijn, Sari Susanna Ormstad, Aino-Liisa Oukka, Andy Oxman, Markku Pekurinen, Ånen Ringard, Risto O. Roine, Risto P. Roine, John-Arne Røttingen, Adolfo Rubinstein, Alric Rüther, OlliPekka Ryynänen, Pirjo Räsänen, Ulla Saalasti-Koskinen, Samuli Saarni, Laura Sampietro-Colom, Joshua Shemer, Uwe Siebert, Sinikka Sihvo, Sue Simpson, Harri Sintonen, Jane E. Sisk, Ken Stein, Rod Taylor, Gus Thompson, Hanne Thorsen, Sean Tunis, Heikki Ukkonen, Raija Vanhala, David Whynes, Claudia Wild, Klaus Witt, and Ambachew M. Yohannes.

We warmly thank our Editorial Board and other reviewers for their valuable scientific input.

Our publisher, Cambridge University Press (CUP), has in September 2010 announced their new policy on open 
access publication. CUP offers authors the option to publish their article as Open Access, on payment of a one-off fee, either 1,500 GBP or 2,700 USD. This option means that the article can be accessed by anyone, regardless of subscription status. All authors whose manuscripts are accepted are now asked if they wish to have their article available openly. More information is available at http://journals.cambridge. org.

The Editorial Office welcomes contacts from authors and readers. Please feel free to contact us at IJTAHC@thl.fi should you have any comments or suggestions to make our Journal even more useful.

\section{CONFLICT OF INTEREST}

M Mäkelä's institute receives a grant from the European Commission. The other author reports having no potential conflicts of interest.
Marjukka Mäkelä, MD, PhD, MSc

Editor-in-Chief

International Journal of Technology Assessment in Health Care

Director of FINOHTA (Finnish Office for Health Technology Assessment) at THL (National Institute of Health and Welfare)

IJTAHC Editorial Office

P.O. Box 30, 00271 Helsinki, Finland

E-mail: IJTAHC@thl.fi

Terhi Ilonen, HCS

Manuscript assistant

IJTAHC Editorial Office

FINOHTA (Finnish Office for Health Technology Assessment) at THL (National Institute of Health and Welfare)

P.O. Box 30, 00271 Helsinki, Finland

IJTAHC Editorial Office 